\title{
A vevői elégedettség mérésének lehetőségei többdimenziós szemléletben
}

Kenesei Zsófia,

a Budapesti Corvinus Egyetem habilitált egyetemi docense

E-mail: zsofia.kenesei@unicorvinus.hu
A vevői elégedettség elérése a versenyelőny megszerzésének egyik fő eszköze, a legtöbb vállalat számára prioritás a stratégia kialakításában. Annak megértése azonban, hogy mi eredményez vevői elégedettséget, korántsem egyértelmü, a szakemberek körében mind a mai napig élénk vita tárgyát képezi. Ahhoz, hogy pontos képet kaphassunk a vevők elégedettségéről és az azt befolyásoló tényezőkröl, jó mérőeszközzel kell, hogy rendelkezzünk. Ezen túl pedig elengedhetetlen az eredmények helyes elemzése is. A gyakorlatban sok vállalat méri a vevői elégedettséget, eredményeik feldolgozására azonban nem mindig rendelkeznek megfelelö eszközzel.

A cikk első része röviden összefoglalja a vevői elégedettség mérésének szempontjait, bemutatja a többdimenziós elégedettségkoncepció lényegét, majd ismerteti a többváltozós regresszióelemzésen alapuló módszerek lényegét. A második rész a mérés és az elemzés empirikus eredményeit tárgyalja egy magyarországi bank lakossági ügyfeleinek reprezentatív mintáján, egyaránt áttekintve a módszertani és a gyakorlati tanulságokat is.

TÁRGYSZÓ:

Elégedettségmérés.

Modellek.

Többváltozós regresszió.

DOI: 10.20311/stat2017.01.hu0029 
Az elégedettséggel foglalkozó cikkek és szakkönyvek nagy száma arra utal, hogy a téma jelentőséggel bír mind a gyakorlati, mind az elméleti szakemberek körében. A vevői elégedettség kérdése központi szerepet játszik a vállalatok életében. Ennek egyik oka, hogy a vevői elégedettség hosszú távon magas vállalati értékhez vezethet, egy másik pedig, hogy a TQM- (total quality management - teljes körü minőségmenedzsment) rendszerek müködtetésének, illetve az ISO- (International Organization for Standardization - Nemzetközi Szabványügyi Szervezet) szabványoknak való megfelelésnek alapvető feltétele a vevői és alkalmazotti elégedettség mérése. Célunk, hogy bemutassuk a többdimenziós elégedettségmérés lehetőségeit, és gyakorlati útmutatót adjunk a témában a vállalkozások számára. A cikk kontextusa a bankszektor, amely számára a gazdasági világválság és a jogi, politikai környezet állandó változása következtében kifejezetten fontossá vált, hogy magas színvonalú szolgáltatást nyújtson. Ugyanakkor az is hangsúlyozandó, hogy e szolgáltató ágazat tekintetében különösen nehéz definiálni és mérni az elégedettséget.

Az elméleti összefoglaló első részében rövid áttekintést adunk az elégedettséghez kapcsolódó kutatási eredményekről, majd rátérünk az elégedettségmérés lehetőségeire, kitérve a minőségmérés témakörére is. A tanulmány második részében az elégedettségi kérdőívek feldolgozási módszereit tárgyaljuk, és bemutatjuk azokat a kevéssé alkalmazott eljárásokat, amelyek, túlmutatva a lineáris regresszión, megbízhatóbb eredményeket adnak, és az elégedettség többdimenziós megközelítésének jobban megfelelő statisztikai eszközöket nyújtanak.

\section{A vevői elégedettség fogalma}

Az elégedettség fogalmára vonatkozó szakirodalom rendkívül szerteágazó, összefoglalásával már több magyar tudományos munka is foglalkozott (HofmeisterSimon-Sajtos [2003], Bátor [2007], Hetesi [2003], Kemény [2015]), ezért magát a fogalmat e cikkben nem tanulmányozzuk behatóan. Szintén nem célunk az elégedettség és a minőség fogalmi keretei közötti eltérések és azonosságok tisztázása. Noha az elégedettség mérésének többdimenziós modelljei a minőség szakirodalmából származnak, elfogadjuk Hofmeister-Simon-Sajtos [2003] álláspontját arra vonatkozóan, hogy egyrészt nincs megnyugtató megoldás a két koncepció elhatárolására, másrészt fölösleges e ténynek nagy jelentőséget tulajdonítani, érdemesebb inkább a párhuzamosságokra, a közös pontokra koncentrálni. 
Jelen cikkben részletesen áttekintjük az elégedettség dimenzióinak mérésére vonatkozó kutatásokat, összegezve a fö tanulságokat. Mielött azonban rátérnénk az elégedettségmérés modelljeire, röviden összefoglaljuk az elégedettség leírására szolgáló elméleti lehetőségeket.

Az elégedettség fogalmának leírására a legelfogadottabb és leggyakrabban alkalmazott koncepciók az elváráselmélet és a diszkonfirmációs paradigma (Oliver [1977], Szymanski-Henard [2001]). Ezek alapján az elégedettség annak a kognitív folyamatnak az eredménye, amely során a vevő elvárásait összeveti a tapasztalataival, s amennyiben az észlelt teljesítmény meghaladja elvárásait, elégedett lesz (pozitív diszkonfirmáció), ha nem, akkor elégedetlen (negatív diszkonfirmáció). A diszkonfirmációs paradigma alapja Helson [1964] alkalmazkodáselmélete, amely azon a feltételezésen alapul, hogy az egyének a külső környezetből származó ingereket egy már meglevő standard alapján értékelik. Az elégedettséggel kapcsolatos kutatások (Oliver [1993]) mutattak rá arra, hogy az egyének a teljesítmények értékeléséhez előzetes elvárásaikat referenciapontként használják, s ilyen módon az elégedettség kialakulása annak függvénye, hogy mi volt a vevő előzetes elvárása (referenciapont), illetve hogy ettől mennyiben tér el tapasztalata (diszkonfirmáció). A diszkonfirmációs paradigma tehát nagy hangsúlyt helyez az elvárásokra, $\mathrm{s}$ annak a kérdésnek a megválaszolására, hogy mi alakítja a fogyasztó elvárásait, s azt milyen módon veti össze tapasztalataival.

Egy másik megközelítés szerint az elégedettség a teljesítménytől függ, azaz a vevő azt mérlegeli, hogy a termék/szolgáltatás mennyiben teljesíti az adott ár mellett vágyait, igényeit. Churchill Jr.-Surprenant [1982] kísérleti módszertant alkalmazva tanulmányozták a teljesítményt és az előzetes elvárások hatását. Eredményeik alapján a tartós fogyasztási cikkek körében egyértelmüen a teljesítmény volt a vevői elégedettség forrása. Teljesítménytényezők vizsgálatával a szolgáltatások minőségmérésében hasonló, ám a diszkonfirmációs paradigmánál megbízhatóbb megállapításra jutott Cronin-Taylor [1994]. A teljesítmény kontextusában gyakran szerepel az ár is, amelyet a vevő fizet a termékért, összehasonlítva azt az azért kapott teljesítménnyel (Johnston [1997]). E gondolatrendszerben tehát az elégedettség része a kapott érték.

Ehhez szorosan kapcsolódik a harmadik megközelítés, amely az igazságosság elméleti keretére épít; eszerint az elégedettség alapja a vevő által érzett igazságosság. Amennyiben a vevő úgy érzi, hogy (akár pénzügyi, akár időbeli vagy érzelmi) befektetései jelentősebbek voltak, mint a kapott ellenérték, akkor elégedetlen lesz. Az igazságosságnak három dimenziója van (Kenesei-Kolos [2008]): a kimenet igazságossága elsősorban a kapott értékre vonatkozik, a folyamat igazságossága arra a módra, ahogy a termékhez, szolgáltatáshoz hozzájutott (például mennyit kellett várnia), míg az interakciós igazságosság a bánásmódra, tehát arra, hogy mennyire voltak udvariasak, kedvesek vele a vásárlás során. Ezt az elméleti keretet elsősorban a szol- 
gáltatásoknál, azon belül is a panaszkezelés során használják az elégedettség kifejezésére.

Végül, az elégedettségi kutatások jelentős elméleti bázisát adja az érzelmi megközelítés. A kutatók szerint az elégedettség kialakulása ugyanis nem pusztán kognitív, hanem érzelmi folyamat is (Westbrook [1987], Mano-Oliver [1993]). A vásárlási folyamat során megélt érzelmek nyomot hagynak a memóriában, s ez befolyásolja az elégedettségröl adott beszámolókat.

Az előbbiekben bemutatott elméleti megközelítések szerint számtalan változó szolgálhat az elégedettség forrásául. Míg a teljesítményalapú elégedettségmodellek elsősorban a termék vagy szolgáltatás jellemzőit tartják az elégedettség alapvető tényezőinek, az elváráselmélet és a diszkonfirmációs paradigma hívei a teljesítményeket és az ezekre vonatkozó elvárásokat hasonlítják össze és építik modelljeikbe. $\mathrm{Az}$ érzelmi alapú elégedettségmodellekben pedig a vásárlás során megélt negatív vagy pozitív érzelem válik az elégedettség forrásává. Minden elégedettségvizsgálatban azonban közös, hogy akár a termék jellemzőin, akár a minőség tényezőin keresztül, meg kell határozni azokat az attribútumokat (tényezőket), amelyek alapján közvetve vagy közvetlenül a vevők értékelhetik elégedettségüket. Az elégedettség tehát multiattributív, azaz több attribútum együttesen alakítja ki a vevő végső elégedettségét, melyek közül egyesekkel elégedett, míg másokkal nem. Az, hogy mely tényezöket vonjuk be a vizsgálatba, az iparágtól, a terméktől/szolgáltatástól, és esetleg attól a vállalati funkcionális területtől is függ, amely a vizsgálatot végrehajtja.

\section{Elégedettségmérési modellek}

Az elégedettség mérése az elmúlt években két vállalati funkcionális terület számára vált különösen fontossá, az egyik a marketing, a másik a minőségbiztosítás. Az előbbiben a vevői elégedettség sok esetben egyfajta piaci hatékonysági mérőszám, és elérése az üzleti siker alapja; míg az utóbbiban a vevői (és dolgozói) elégedettség mérése a TQM- és ISO-rendszerek elterjedésével vált fontossá. Bár mindkét terület tudományos közélete foglalkozik a témával, szemléletük sok esetben eltérö.

Az elégedettségmérés célja azonban minden esetben azoknak az attribútumoknak a meghatározása, amelyek leginkább befolyásolják a vevői elégedettséget, és amelyek fejlesztése a legnagyobb mértékben növelheti a termékkel/szolgáltatással való „összelégedettséget”, így arra érdemes erőforrásokat allokálni. Míg a marketingtudomány elsősorban egydimenziós minőségmodelleket alkalmaz, addig a tevékenységmenedzsment és a minőségbiztosítás területén a két- vagy többdimenziós modellek terjedtek el. 


\subsection{Egydimenziós megközelítések}

Az elégedettség mérésére leggyakrabban alkalmazott egydimenziós módszerek szerint minél magasabbra értékeli a vevő a termék egy meghatározott tulajdonságát, annál nagyobb lesz az összelégedettsége. A szolgáltatások minőségmérésében elterjedt a SERVQUAL- (service quality - szolgáltatások minősége) skála (ZeithamlBerry-Parasuraman [1996], Kenesei-Szántó [1998]), amely a dimenziók valós és elvárt teljesítménye közötti különbség hatását méri éppúgy, mint a teljesítmény mérésén alapuló SERVPERF- (service performance - szolgáltatások teljesítménye) skála (Cronin-Taylor [1994]). Az egydimenziós megközelítés alkalmazói azzal a hipotézissel élnek, hogy mindegyik attribútum egyformán (lineárisan és szimmetrikusan) hat az elégedettségre/elégedetlenségre: minél magasabb azok színvonala, annál nagyobb fokú lesz az elégedettség, illetve minél alacsonyabb, annál nagyobb az elégedetlenség.

Az elégedettségmérés egy másik kutatási iránya az IPA (importance-performance analysis - fontosság-teljesítmény analízis). Ebben két dimenzió szerint értékelik az elégedettséget: egyrészt az adott attribútum teljesítményét (gyakorlatilag az adott tulajdonsággal való elégedettséget), másrészt fontosságát is mérik (Martilla-James [1977]). Ezek alapján egy négyosztatú mátrixban meghatározzák azokat a dimenziókat, amelyek esetén a vállalat 1 . megfelelően teljesít (cél: az eddigiek folytatása); 2 . amelyek fontosságukhoz képest alacsonyabb teljesítményt nyújtanak (cél: ide kell koncentrálni) vagy 3. túlteljesítenek (cél: túlteljesítés visszafogása); míg a 4 . negyedben a nem fontos és nem is jól teljesítő attribútumok sorakoznak (cél: alacsony prioritás). Bár már két dimenziót használ, az IPA továbbra is azt feltételezi, hogy az egyes dimenziók teljesítménye és az elégedettség közötti kapcsolat lineáris és szimmetrikus, ezért az egydimenziós megközelítések közé sorolható.

\subsection{Kétdimenziós megközelítések}

Az elégedettség dimenzióinak és az összelégedettség kapcsolatának feltárása során több kutató is arra az eredményre jutott, hogy az sok esetben nem lineáris vagy szimmetrikus. A gyakorlatban sokszor tapasztalható, hogy egyes terméktulajdonságok hiányának sokkal nagyobb jelentősége van a vevő számára, mint azok meglétének. Tehát hiába teljesítünk jól számtalan tényező tekintetében, ha az egyik teljesítménytényező alacsony színvonalú, akkor a vevők elégedettsége erőteljesen csökken. Emellett azt is meg kell említeni, hogy az egyes tényezők hatása nem növelhető bármeddig: egy ponton túl ugyanis már nem növelik az elégedettséget. Ezt az aszimmetrikus, nem lineáris kapcsolatot Kahneman-Tversky [1979] kilátáselmélete írja le, amely alapján Mittal-Ross-Baldasare [1998] S-alakú görbével jellemezték a termék 
tulajdonságai és az elégedettség közötti kapcsolatot. A kilátáselmélet két alapvetése, a veszteségkerülés és a csökkenő hozadék elve az elégedettség esetében azt jelenti, hogy egy tényező egységnyi romlása nagyobb mértékben fokozza az elégedetlenséget, mint egységnyi növekedése/javulása az elégedettséget (a kapcsolat aszimmetrikus). Egy tényezö teljesítményének növekedése viszont egyre kisebb mértékủ elégedettségnövekedést, illetve -csökkentést okoz (a kapcsolat nem lineáris). Mittal-RossBaldasare [1998] kutatása az autóiparban hat tényezőből öt esetében igazolta az Salakú görbét. A szerzők ugyanakkor a hatodik tényezőnél (gépjárművek tágassága) fordított eredményt kaptak: annak pozitív irányú változása erőteljesebb hatással volt az elégedettség növekedésére, mint negatív irányú változása az elégedettség csökkenésére. Erre magyarázat a termékek attribútumainak sokféleségében kereshető. Léteznek ugyanis olyanok, amelyek elsősorban az elégedettséget növelik, míg mások az elégedetlenséget csökkentik.

Ez a gyakorlatban azt jelenti, hogy van néhány olyan jellemző, amelyek hiánya nem teszi elégedetlenné a vevőt, ha viszont a termék rendelkezik ezekkel, akkor elégedettsége jelentősen nő. Ennek ellentéte is igaz lehet: egyes jellemzők nem járulnak jelentősen hozzá az elégedettséghez, hiányuk azonban nagyban fokozza az elégedetlenséget. Az utóbbiakat más kutatásokban „dissatisfiers-nek”, azaz elégedetlenségre okot adó (más néven alap-) tényezőknek hívják (Cadotte-Turgeon [1988], Johnston [1995]). A szolgáltatások esetében gyakran a fizikai környezetet tekinthetjük alaptényezőnek, hiszen például egy színházban azt, hogy a székek mennyire kényelmesek, nem gondoljuk elégedettségünk legfontosabb forrásának, azonban erőteljesen rontja összelégedettségünket, ha azok kényelmetlenek.

\subsection{Három- és többdimenziós megközelítések}

Az empirikus kutatások során sok esetben találkozni azzal a jelenséggel, hogy vannak olyan tényezők, amelyek nemcsak az elégedetlenséget csökkentik, hanem az elégedettséget is növelik. Ez a jelenség ellentmond a kétdimenziós modelleknek, amennyiben azok két külön csoportba sorolják a tényezőket: az elégedetlenséget csökkentőkre és az elégedettséget növelőkre. Azokat a tényezőket, amelyek „lefelé” és „felfelé” is egyformán hatnak, gyakorlatilag az egytényezős modellekhez hasonlóan kell figyelembe venni, hiszen ezek hatása lineáris és szimmetrikus. E jelenség leírására a kutatók három dimenzióba sorolták a jellemzőket: alap(basic/must [elengedhetetlen]), teljesítmény- (performance/one-dimensional [egydimenziós]) és lelkesítő (excitement/value-enhancer [értéknövelö]/attractive [vonzó]) tényezők. Amint a többféle angol nyelvü meghatározás is mutatja, a kutatások eltérő kiindulópontból, de ugyanazt a jelenséget írják le a három dimenzió segítségével. 
Az alaptényezők meglétét a vevők nélkülözhetetlennek tartják. Ha teljesítményük nem ér el egy alapszintet, akkor elégedetlenek lesznek; a fölött viszont nem okoznak további elégedettségnövekedést. Bevonva e tényezőket az elégedettségfüggvénybe, hatásuk az elégedettségre viszonylag alacsony lesz, viszont ha értékük egy kritikus szint alá csökken, drámai hatást gyakorolnak az elégedetlenségre.

A lelkesítő tényezők hiánya nem vezet elégedetlenséghez, szintjük emelése azonban rendkívüli elégedettséget okoz. Banki kutatásokban ilyen tényező például az ügyintézők figyelmessége, kedvessége (Arbore-Busacca [2009], Johnston [1995]). $\mathrm{Az}$ elégedettségfüggvényben hatásuk jelentős lehet, azonban alacsony szintjük nem vezet elégedetlenséghez. E tényezők fontossága tehát nagyságuk függvénye (ami ellentmond az IPA azon alapfeltevésének, hogy a teljesítmény és a fontosság egymástól független változók).

A harmadik csoportot alkotó teljesítménytényezők hatása lineáris és szimmetrikus az elégedettségre, tehát minél több ezek száma, jobb a minőségük/hatásfokuk stb., annál magasabb fokú lesz a vevői elégedettség, míg ellenkező esetben kisebb fokú. Ide általában viszonylag jól mérhető és kommunikálható technikai paraméterek (például egy gépjármü biztonsági felszereltsége vagy a bankfiókok száma) tartoznak.

E három tényező mellett Kano [1984] számba veszi a fordított hatású és az indifferens tényezőket is. Míg az előbbiek a teljesítménytényezőkkel ellentétesen hatnak (azaz minél magasabb a szintjük [például károsanyag-kibocsátás vagy fogyasztás], az elégedettség foka annál alacsonyabb), addig az utóbbiak megléte vagy hiánya egyáltalán nem befolyásolja a fogyasztói döntéseket. Kano öttényezős modellje elsősorban a minőségbiztosítás terén nyert elfogadottságot (Matzler-Hinterhuber [1998], Chang-Chen-Hsu [2012]).

\section{Az elégedettség mérésének módszerei}

A bemutatott elégedettségmérési modellek eltérő mérési módszereket alkalmaznak. Az egydimenziós modellek esetén a legszélesebb körben alkalmazott mérési eszköz a SERVQUAL-skála, illetve annak változatai. Az eredeti skála $2 \times 22$ állítást tartalmaz (a teljesítmény és az elvárások mérésére), amelyek öt faktort képeznek: megfogható elemek, megbízhatóság, reagálási készség, biztonság, empátia. A minőségfaktorok és az elégedettség közötti összefüggés regresszióanalízis segítségével vizsgálható. Parasuraman-Zeithaml-Berry [1988] a diszkonfirmációs paradigmára építettek, ezért elemzésükbe a teljesítmény és az elvárások közötti különbségeket vonták be, ami már önmagában is felvet néhány pszichometriai problémát (PeterChurchill Jr.-Brown [1993]). Az eltérésösszegeket aztán a válaszadók által megadott 
fontossági súlyokkal súlyozták. Az öt dimenzióról azóta sokan bebizonyították (például Cronin-Taylor [1994]), hogy nem stabilak. Továbbá a regressziós eredményeket a multikollinearitás is torzítja, amit Parasuraman-Zeithaml-Berry [1988] maguk is problémának tartottak.

Az újabb alkalmazások PLS-SEM- (partial least squares structural equation modelling - parciális legkisebb négyzetek módszer a strukturális egyenletek modelljén belül) útelemzést használnak (a részletes leírásért lásd Kazár [2014], Kovács [2015], Krenyácz [2015]), amely bizonyos mértékig feloldja a változók közötti összefüggések problémáját, de továbbra is lineáris és szimmetrikus kapcsolatot tételez fel a termékattribútumok és az elégedettség között. Itt kell megemlítenünk, hogy az elégedettség mérésének teljesítményalapú modelljei alapvetően formatív skálák, míg a tudományos kutatásokban sokszor reflektív skálák szerepelnek, amelyek azonban nem alkalmasak a dimenziók fontosságának mérésére (a reflektív és formatív modellekről részletesen lásd Szöcs-Berács [2015]).

A teljesítmények és elvárások hatásának vizsgálata mellett gyakran alkalmazzák a gyakorlatban elégedettségmérésre az IPA-megközelítést is, azaz az egyes tényezők fontosságát kifejező értékkel súlyozzák a mért teljesítményeket. A fontosság mérésére többféle módszer is létezik, hagyományos eljárás a skálázás, de a rangsorolást vagy egy bizonyos pontszám (általában 100) szétosztását is alkalmazzák (MatzlerSauerwein [2002]). Ez utóbbi megoldás csak viszonylag kevés számú attribútum mellett alkalmazható. Vavra [1997] a fontosság explicit mérésének kapcsán felvetette, hogy ha az attribútumok és az elégedettség közötti összefüggés $S$ alakú görbével írható le, akkor egy tényező fontossága az elégedettség változásával együtt csökkenhet/nőhet. A fontosság tehát nem független az elégedettségtől. Ezért a kutatásoknál gyakran fordul elő az a helyzet, hogy a válaszadók az alaptényezők (például a banki ügyletek biztonságosságának, a pontos számlavezetésnek a) fontosságát nagyon nagyra értékelik, míg a lelkesítő tényezőknek (például a banki alkalmazott figyelmességének) nem tulajdonítanak akkora jelentőséget. Ez azzal magyarázható, hogy az alaptényezők a termék minimálisan elvárható tulajdonságait takarják, nélkülük nem képzelhető el az adott termék. Hiányuk tehát rendkívül kellemetlenné válhat, így explicit (a fogyasztók által kinyilvánított) fontosságuk nagy. Magas szintủ teljesítésük azonban nem növeli az elégedettséget, tehát az elégedettség növekedésével súlyuk csökken. Ezekkel szemben viszont az elégedettséget rendkívüli módon növelö lelkesítő tényezők fontossága az explicit mérésben rendszeresen alacsonyabb értékeket kap. Mindez arra mutat, hogy a vevők által megadott fontossági értékek félrevezetők lehetnek, hiszen azok az elégedettség mértékéhez kötődnek (MatzlerSauerwein-Heischmidt [2003]).

Az egydimenziós modellek mellett az elégedettségi kutatásoknak egy kevésbé kvantitatív vonulata is rávilágított arra a tényre, hogy a tényezők nem ,szimmetrikusan" hatnak az elégedettségre. E kutatások nagy része a tartalomelemzés, legtöbbször 
a kritikus esetek módszerével dolgozik (Gremler [2004]). Az utóbbi vevői interjúk tartalomelemzésével határozza meg azokat a tényezőket, amelyek a legtöbb pozitív vagy negatív reakciót váltják ki a vevőkből. A kritikus esetek módszerének úttörő jelentősége volt abban, hogy rávilágított az elégedettség és az elégedetlenség eltérő dimenzióira (például Meuter et al. [2000]).

A háromdimenziós modellek esetén többféle mérési módszert említ a szakirodalom. Vavra [1997] a válaszadók által érzékelt explicit fontosság mellett a teljesítménymutatókból (az attribútum összelégedettséggel való kapcsolatát kifejező) implicit fontosságot is számít, $\mathrm{s}$ a két érték összevetésével adja meg a három dimenziót. Az összelégedettséget mint függő változót és a teljesítménytényezőket mint független változókat regressziós elemzésbe vonva, a standardizált $\beta$ értékek segítségével határozható meg az egyes tényezők implicit fontossága. Így felrajzolható (az implicit és explicit fontosságok dimenzióival) az IPA-ból ismert négyosztatú mátrix, amelynek cellái a különböző dimenziókat jelzik: a mind explicit, mind implicit fontosságú tényezők a teljesítménytényezők; a magas explicit, de alacsony implicit fontosságúak (például a bank biztonságossága) az alaptényezők; míg a magas implicit, de alacsony explicit fontosságúak (például ügyintézők kedvessége) a lelkesítő tényezők. Az alacsony implicit és alacsony explicit fontosságú tényezőknek nincs hatásuk az elégedettségre.

A többdimenziós modellek egy másik, széles körben elfogadott mérési módszere szerint dummy változókat alakítanak ki attól függően, hogy elégedettséget vagy elégedetlenséget kiváltó tényezőről van-e szó. Ennek első változata Brandt [1988] nevéhez füződik (a módszert penalty-reward [büntetés-jutalmazás] módszernek is nevezik), aki ötfokozatú skálát használt a diszkonfirmáció mérésére ,az elvártnál sokkal jobb” végponttól „az elvártnál sokkal rosszabb” végpontig. Brandt a válaszadókat az alapján csoportosította, hogy azok elvárásai felett (két felső érték), alatt (két alsó érték) vagy éppen azoknak megfelelően (középérték) teljesített-e az adott tényező. Majd összehasonlítva a csoportok elégedettség-átlagértékeit, azok szignifikáns eltéréseit vizsgálta. Azokat a tényezőket, amelyek esetén az átlagértékek 1. szignifikánsan magasabbak voltak ,az elvárásoknál jobban teljesített” csoportban, mint az „éppen megfeleltben", lelkesítő tényezőknek; 2. szignifikánsan alacsonyabbak voltak az „elvárásoknál rosszabbul teljesített” csoportokban, mint az „éppen megfeleltben”, alaptényezőknek; 3. szignifikánsan eltértek egymástól mindhárom csoportban, teljesítménytényezőknek tekintette.

Az előbbi módszer továbbfejlesztett változata a dummy változók bevonása a regressziós egyenletbe (Anderson-Mittal [2000], Matzler-Sauerwein [2002], MatzlerRenzl-Faullant [2007]). Ebben az aszimmetrikus teljesítmény-elégedettség kapcsolat feltárása érdekében kétféle dummy változót hoznak létre. Az első típussal az alaptényezők hatását mérik, míg a másodikkal a lelkesítő tényezőket. A változók meghatározásához újrakódolják a teljesítményváltozókat, és így az alacsony teljesítményüek 
a $(0 ; 1)$, a magas teljesítményüek az $(1 ; 0)$, míg az átlagosak a $(0 ; 0)$ értéket kapják. Ezután többváltozós regresszióanalízist végeznek a következő egyenlet alapján:

$$
Y=\beta_{0}+\beta_{1 j} \cdot D_{1 j}+\beta_{2 j} \cdot D_{2 j} \quad j=1,2, \ldots, m,
$$

ahol $Y$ jelöli az összelégedettséget, $j$ az értékelésbe vont tulajdonságok (attribútumok) sorszámát, $D_{1 j}$ a j-edik tulajdonsággal való elégedettség dummy változóját ( $D_{1 j}=1$, ha a tulajdonsággal különösen elégedett volt a válaszadó, és 0 , ha nem volt az), míg $D_{2 j}$ a $j$-edik tulajdonsággal való elégedetlenség dummy változóját ( $D_{2 j}=1$, ha az adott tulajdonsággal elégedetlen volt a válaszadó, és 0 , ha nem volt az).

Meg kell jegyeznünk, hogy ennél a módszernél a dummy változók képzése során a kutató maga határozza meg azt a szintet, ahol meghúzza az elégedettség és az elégedetlenség határát. Ennek értéke tehát függ az alkalmazott skálától és a kutató döntésétől is. Arbore-Busacca [2009] tízes skálán 1-töl 4-ig elégedetlennek, míg 7 fölött elégedettnek tekintette a válaszadókat. Matzler-Renzl-Faullant [2007] szintén tízes (1-6 elégedetlen, 7-10 elégedett), míg Matzler-Sauerwein [2002] ötös skálát alkalmazott, az utóbbiak a legmagasabb értéket (nagyon elégedett) a lelkesítő tényezők, az alsó két értéket (nagyon elégedetlen és valamennyire elégedetlen) az alaptényezők meghatározásához használták, a 3-at és a 4-et (közömbös, illetve valamennyire elégedett) pedig referenciaként az előző két csoporttal való összehasonlításra. Általánosságban elmondható, hogy a kutatók a lelkesítő tényezők vonatkozásában a teljesítményskála felső értékeit veszik figyelembe, míg az alaptényezők feltárásához a közepeseket vagy annál rosszabbakat. A kettő között van az ún. semleges zóna, amikor nem különösen elégedett vagy nem elégedetlen a válaszadó az adott tényező teljesítményével. Egy másfajta megközelítés nem a skálákat, hanem a válaszokat veszi kiindulási alapul, és a válaszadók felső harmadára vonatkozó értékeket használja az elégedettség, míg az alsó harmadot az elégedetlenség meghatározására (Mittal-Ross-Baldasar [1998], Matzler-Renzl-Faullant [2007]). Ebben a megközelítésben az egyes dimenzióknál ki lehet szürni az eloszlás ferdeségének a hatását, ami miatt nagyon kevés lenne a skála alsó, illetve felső értékeit választó válaszadók száma (attól függően, hogy az melyik irányban ferde).

A regressziós egyenlet $\beta_{1 j}$ és $\beta_{2 j}$ koefficiensei alapján megállapítható, hogy az adott tulajdonság pozitív/negatív megítélése szignifikánsan befolyásolja-e az összelégedettséget. Az első tényező szignifikáns értéke esetében lelkesítő tényezőről beszélhetünk, a második esetében alaptényezőről, míg ha mind a két koefficiens szignifikáns, akkor teljesítménytényezőről van szó, amelynek hatása szimmetrikus. 
E módszert alkalmazták Anderson-Sullivan [1993], majd Mittal-Ross-Baldasar [1998] is azzal a kiegészítéssel, hogy a teljesítményváltozók természetes logaritmusát vonták be az elemzésbe a következő módon:

$$
Y=\beta_{0}+\beta_{1 j} \cdot \ln P_{-} X_{j}+\beta_{2 j} \cdot \ln N_{-} X_{j} \quad j=1,2, \ldots, m
$$

ahol $Y$ jelöli az összelégedettséget, $j$ az értékelésbe vont tulajdonságok (attribútumok) sorszámát, $\ln P_{-} X_{j}$ a j-edik tulajdonsággal való elégedettség értékeinek természetes logaritmusát, amennyiben a válaszadó a -4-től +4-ig tartó skálán 1-et, 2-őt, 3-at vagy 4-et jelölt meg, egyéb esetben $0, \ln N_{-} X_{j}$ a $j$-edik tulajdonsággal való elégedetlenség értékeinek természetes logaritmusát, amennyiben a válaszadó a -4-töl +4-ig tartó skálán -1-et, -2-öt, -3-at vagy -4-et jelölt meg, egyéb esetben 0 .

Ezzel a módszerrel a szerzők nemcsak az aszimmetrikus kapcsolatot vették figyelembe, hanem a csökkenő érzékenységet is, azaz a tényezők teljesítménye és az elégedettség közötti nem lineáris kapcsolatot. Eredményeik alapján az aszimmetrikus kapcsolat beigazolódott, azonban a csökkenő hatás nem volt egyértelmủ. Ting-Chen [2002] összevetették a logaritmusalapú modellt a lineárissal; eredményeik szerint mindkét modell elfogadható illeszkedést mutat, és egyik sem teljesít jobban a másiknál.

A Kano-modell alapján dolgozták ki az ún. Kano-kérdőívet, amellyel direkt módon mérik az elégedettség és az elégedetlenség dimenzióit (Matzler-Hinterhuber [1998], Chang-Chen-Hsu [2012]). Ez elsősorban a müszaki termékfejlesztésben vált népszerüvé, és továbbfejlesztett változatait a QFD (quality function deployment minőség háza) megközelítésben alkalmazzák. Többek között Chen-Weng [2003] és Chen-Ko [2008] egy fuzzy, nemlineáris módszert javasoltak, amely a Kano-modellre alapozva segíti a minőségkomponensek hatásának maximalizálását a vevői elégedettség szempontjából.

Amint az elözőekben bemutattuk, az elégedettségmérés statisztikai módszere az esetek többségében a regresszióelemzés. A regressziós módszerek fejlődésével új típusú elégedettségmérési lehetőségek is rendelkezésre állnak, melyek egyike a játékelméleten alapul. E regressziószámítást Pintér [2007] regressziós játékoknak nevezi, amelyek célja, hogy a modell illeszkedését jelző $R^{2}$ mutatót felosszák a változók fontosságának megfelelően. Ebben az esetben a regresszió egyfajta kooperatív játéknak tekinthető, amelyre az átruházható hasznosság jellemző: a magyarázó változók a játékosok, az illeszkedés pedig az általuk közösen elért eredmény, ami szétosztható közöttük, (a játékosok kifizetése) (Pintér [2007]). Becsléshez Pintér a Shapley-értéket alkalmazza, amely meghatározza, hogy az egyes játékosok (esetünkben attribútumok) miként járulnak hozzá a különböző koalíciók (játékok [regressziók]) értékéhez, és ezeknek a határértékeknek az átlagát kapják meg a játékosok kifi- 
zetésként. A Shapley-érték értelmezésekor tehát megvizsgáljuk azokat a koalíciókat, amelyekben nem szerepel a vizsgált változó, majd a többi koalíciót aszerint tanulmányozzuk, hogy azok értékéhez a változó miként járul hozzá. A Shapley-érték az öszszes lehetséges regressziós modellt elemzi, és az egyes magyarázóváltozók hatásainak azonos súllyal vett összegét rendeli az adott attribútumhoz. A Shapley-érték használatának előnye, hogy abban az esetben, ha a független változók erösen korrelálnak egymással, azonos fontossági súlyt kapnak, és a modell nem preferálja egyik attribútumot sem (Lipovetsky-Conklin [2001]), illetve nem ad negatív értéket erős korreláció esetén (ami a „normál” lineáris regresszió során könnyen előfordulhat). Mindez megbízhatóbb értékelési lehetőséget biztosít a vezetők számára, és ha nem ismerik a korreláció okát, akár az összes összefüggő tényezőre egyaránt odafigyelhetnek az erőforrások allokálásánál. A Shapley-regressziót alkalmazzák ConklinPowaga-Lipovetsky [2004] is a többdimenziós elégedettségi modellek becslése során, és az elégedettségre okot adó tényezőket éppúgy meghatározzák vele, mint az elégedetlenségre okot adókat. A Shapley-értéken alapuló regresszió más üzleti döntések (például az online konverziót befolyásoló tényezők hatásának becslése) meghozatalára is alkalmas (Nisar-Yeung [2015]).

\section{A szolgáltatásattribútumok vevői elégedettségre gyakorolt aszimmetrikus hatásának mérése egy banki példán keresztül}

A következőkben az előbb említett elégedettségmérési lehetőségek közül egy dummy változókon alapuló, az aszimmetrikus hatásra rávilágító, háromdimenziós módszert mutatunk be valós adatokon. A módszer előnye, hogy könnyen adaptálható a mindennapi vállalati gyakorlatban, mert a vállalatok által elterjedten használt elégedettségmérési kérdőívek teljesítményre és összelégedettségre vonatkozó kérdéseit használja fel. Jelen elemzés a GfK Hungária Piackutató Intézet Retail Banking Monitor kutatásának 2013-as adataira épül. Ezt évente négy hullámban hajtják végre egy országos reprezentatív mintán; a személyesen megkérdezettek egy standard kérdőíven - sok más mellett - a bankjukkal kapcsolatos véleményükről is nyilatkoznak. Kutatásunkhoz az adatbázisból egy bankot választottunk ki, és azokkal a kérdésekkel (illetve a rájuk adott válaszokkal) foglalkoztunk, amelyek az ügyfelek e pénzügyi intézménnyel való elégedettségét firtatják. ${ }^{1}$ (A kérdőív általunk vizsgált kérdéseit lásd az 1. táblázatban.) Az ügyfelek válaszaikat ötfokozatú Likert-skálán adták meg.

\footnotetext{
${ }^{1}$ Mivel alapvetően a módszer bemutatása és nem a konkrét bank adatainak ismertetése a célunk, jelen tanulmányban nem közöljük a minta összetételét, illetve nem részletezzük az elemzés feltételeinek megvalósulását sem, hangsúlyozva azonban, hogy ezek vizsgálata kutatásunk fontos részét képezte.
} 
Az 1. táblázatban szereplő 14 kérdést kiegészítettük egy, az összelégedettségre vonatkozóval is: „Mindent összevetve mennyire elégedett Ön a bankjával?” Az adattisztítás után 262 ügyfél válaszait elemeztük. Az elégedettség teljesítménymutatóira vonatkozóan először faktorelemzést végeztünk, hiszen a 14 tételes skála egyes tételei erős korrelációt mutattak, ami nem tette lehetővé a regresszióelemzésbe való bevonásukat, és nehézkessé tette volna az eredmények értelmezését is. A faktorelemzés során így öt jól elkülöníthető dimenziót kaptunk, amelyeket szintén az 1. táblázat mutat be.

\begin{tabular}{|c|c|c|c|c|c|}
\hline \multirow{2}{*}{ Tényező és a Cronbach-féle $\alpha$} & \multicolumn{5}{|c|}{ Faktor } \\
\hline & 1 & 2 & 3 & 4 & 5 \\
\hline Cronbach-féle $\alpha$ & 0,889 & 0,874 & 0,922 & 0,800 & 0,833 \\
\hline $\begin{array}{l}\text { Mennyire elégedett Ön bankjával a következö szempontok } \\
\text { tekintetében: az ügyintézők barátságossága? }\end{array}$ & 0,832 & & & & \\
\hline az ügyintéző szakértelme pénzügyekben? & 0,804 & & & & \\
\hline az ügyintézés gyorsasága? & 0,771 & & & & \\
\hline segítség pénzügyei intézésében? & 0,634 & & & & \\
\hline a termékválaszték nagysága? & & 0,758 & & & \\
\hline a bank ajánlatai az ön számára? & & 0,653 & & & \\
\hline a szolgáltatások minősége? & & 0,639 & & & \\
\hline a bank megbízhatósága, pontossága? & & 0,628 & & & \\
\hline a bank betéti kamatai? & & & 0,901 & & \\
\hline a bank hitelkamatai, költségei? & & & 0,893 & & \\
\hline a bankautomaták (ATM-ek) száma? & & & & 0,910 & \\
\hline a bankfiókok száma? & & & & 0,843 & \\
\hline a bank internetes szolgáltatása? & & & & & 0,869 \\
\hline a bank telefonos szolgáltatása? & & & & & 0,782 \\
\hline
\end{tabular}

Megjegyzés. A faktorok elnevezése a következő: 1. ügyintézők teljesítménye; 2. banki termékek minősége és megbízhatósága; 3. kamatok és költségek; 4. bankfiókok és ATM-ek elérhetősége; 5. telefonos és internetes szolgáltatásminőség. Kaiser-Meyer-Olkin-kritérium: 0,882; vizsgálatunk során varimax rotációt alkalmaztunk; magyarázott szórás $=80$ százalék.

Első lépésként megvizsgáltuk, hogy a válaszadók milyen explicit és implicit fontosságot rendelnek az egyes tényezőkhöz. Az utóbbi feltárásához regresszióelemzést végeztünk a faktorelemzés során kapott faktorokkal. A standardizált $\beta$ értékek alapján meghatározhatjuk, hogy az egyes dimenziók milyen mértékben hatnak az 
összelégedettségre, mennyire fontos a szerepük az elégedettség kialakulásában. Az eredményeket a 2. táblázat foglalja össze.

A bankiszolgáltatás-dimenziók implicit fontosságának meghatározására végzett regressziós becslés eredménye

\begin{tabular}{|c|c|c|c|c|c|}
\hline \multirow{2}{*}{ Faktor } & \multicolumn{2}{|c|}{$\begin{array}{l}\text { Nem standardizált } \\
\text { együttható }\end{array}$} & \multirow{2}{*}{$\begin{array}{c}\text { Standardizált } \\
\text { együttható } \\
(\beta)\end{array}$} & \multirow{2}{*}{$t$} & \multirow{2}{*}{$p$-érték } \\
\hline & $B$ & $\begin{array}{l}\text { Standard } \\
\text { hiba }\end{array}$ & & & \\
\hline Konstans & 4,039 & 0,024 & & 168,230 & 0,000 \\
\hline Ügyintézők teljesítménye & 0,254 & 0,024 & 0,387 & 10,552 & 0,000 \\
\hline Banki termékek minősége és megbízhatósága & 0,352 & 0,024 & 0,537 & 14,618 & 0,000 \\
\hline Kamatok és költségek & 0,174 & 0,024 & 0,266 & 7,237 & 0,000 \\
\hline Bankfiókok és ATM-ek elérhetősége & 0,194 & 0,024 & 0,296 & 8,068 & 0,000 \\
\hline Telefonos és internetes szolgáltatásminőség & 0,116 & 0,024 & 0,177 & 4,819 & 0,000 \\
\hline
\end{tabular}

Megjegyzés. Függő változó: „Mindent összevetve mennyire elégedett Ön a bankjával?”; $R^{2}=0,628$; korrigált $R^{2}=0,621 ; F=93,147(p<0,000)$.

Az elemzés alapján levonhatjuk azt a következtetést, hogy a lineáris, egydimenziós megközelítés szerint a banki termékek minősége és megbízhatósága határozza meg a legnagyobb, míg a telefonos és internetes szolgáltatásminőség a legkisebb mértékben az ügyfelek elégedettségét. Minden tényezőnek szignifikáns hatása van az összelégedettségre. A tényezők explicit és implicit fontosságának összehasonlítására a kérdőív azon kérdésére adott válaszokat használtuk fel, amelyben a válaszadók (1-től 5-ig terjedő Likert-skálán) kinyilvánították, hogy e tényezők mennyire fontosak számukra: „Mennyire fontosak Önnek ezek a dolgok, ha egy bankra, pénzintézetre gondol?" Ebben az esetben is az 1. táblázatban bemutatott, faktoranalízis alapján képzett változókat vizsgáltuk. Ennek megfelelően az adott faktorba tartozó állításokat átlagoltuk, és így határoztuk meg az egyes faktorok fontossági súlyát. Az összehasonlítás végeredményét az 1 . ábra mutatja be. A válaszadók által kinyilvánított (explicit) és a regressziós becslés alapján kapott (implicit) fontosságok némileg eltérő képet mutatnak.

A válaszadók az ügyintézők teljesítményét tartották a legfontosabbnak, a bankfiókok és ATM-ek elérhetőségét pedig a legkevésbé fontosnak, amikor preferenciáikról kérdeztük őket. Ezzel ellentétben implicit módon a banki termékek minőségének és megbízhatóságának van a legjelentősebb hatása az elégedettségre, míg a telefonos és az internetes szolgáltatások minőségének a legkisebb. A kamatok és költségek 
szerepe a válaszadók megítélése szerint nagyobb, mint az összelégedettségre való hatás alapján megállapított.

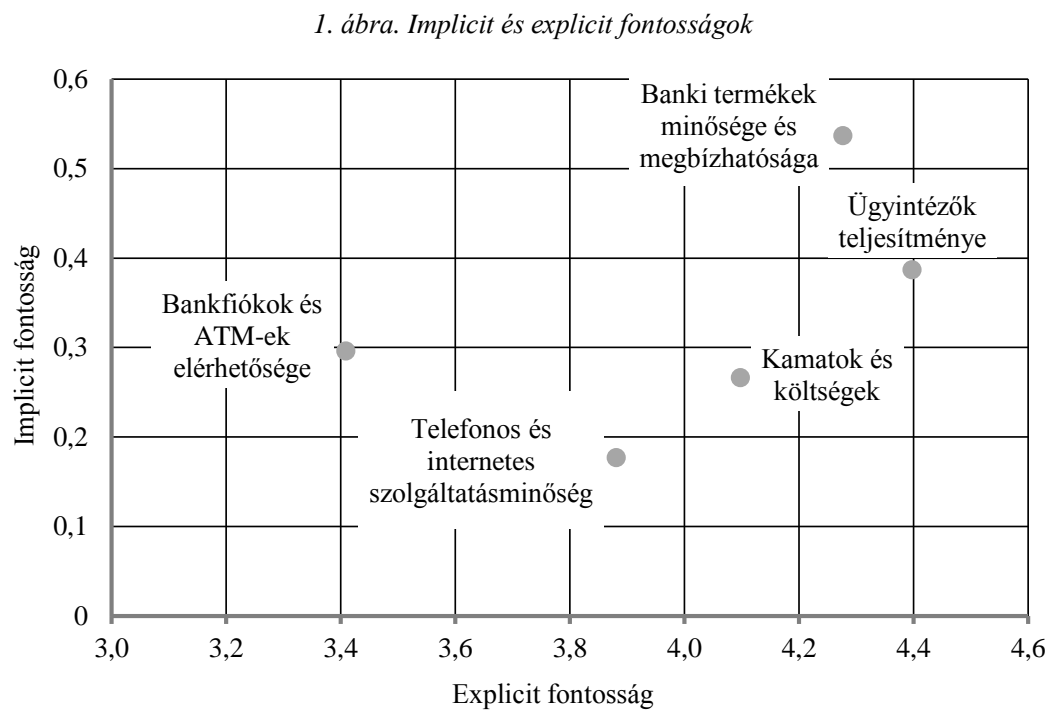

Az elégedettség többdimenziós mérésére a Brandt [1988] által kidolgozott büntetés-jutalmazás módszert alkalmaztuk, Matzler-Renzl-Faullant [2007] javaslatai alapján átdolgozva. Ez lehetőséget adott arra, hogy az elégedettséget a három fajta (lelkesítő, alap- és teljesítmény-) tényező alapján tudjuk értékelni.

A további vizsgálathoz is a faktorokat használtuk. A dummy változók képzéséhez először az adatok felső harmadánál húztuk meg a határt, és az ennél magasabb értéket adó eseteket pozitív teljesítmény-dummyként definiáltuk (melynek értéke 1, ha magasabb, mint a felső harmad; 0 , ha alacsonyabb), míg az alsó harmadnál alacsonyabb értéket adó esetek adták a negatív dummy változó kiindulópontját (melynek értéke 1, ha alacsonyabb, mint az alsó harmad; 0 , ha magasabb). A középső harmad egyfajta referencia volt $(0,0)$, ennek elégedettségértékét a konstans adta meg a 10 változóval felírt regresszióegyenletben (lásd az /1/ képletet), amelyek közül 2-2 dummy változó vonatkozott az öt faktorral való elégedettségre (D1), illetve elégedetlenségre (D2).

A regresszióelemzés eredményeit a 3. táblázatban foglaltuk össze. 
Regressziós becslés dummy változókkal

\begin{tabular}{|c|c|c|c|c|c|}
\hline \multirow{2}{*}{ A faktorok dummy változói } & \multicolumn{2}{|c|}{$\begin{array}{l}\text { Nem standardizált } \\
\text { együttható }\end{array}$} & \multirow{2}{*}{$\begin{array}{c}\text { Standardi- } \\
\text { zált együ̈t- } \\
\text { ható } \\
(\beta)\end{array}$} & \multirow{2}{*}{$t$} & \multirow{2}{*}{$p$-érték } \\
\hline & $B$ & $\begin{array}{l}\text { Standard } \\
\text { hiba }\end{array}$ & & & \\
\hline Konstans & 4,205 & 0,101 & & 41,638 & 0,000 \\
\hline D1_Ügyintézök teljesítménye & 0,196 & 0,071 & 0,144 & 2,770 & 0,006 \\
\hline D2_Ügyintézök teljesítménye & $-0,305$ & 0,073 & $-0,220$ & $-4,187$ & 0,000 \\
\hline D1_Banki termékek minősége és megbízhatósága & 0,226 & 0,077 & $\mathbf{0 , 1 6 9}$ & 2,942 & 0,004 \\
\hline D2_Banki termékek minősége és megbízhatósága & $-0,505$ & 0,075 & $-0,362$ & $-6,717$ & 0,000 \\
\hline D1_Kamatok és költségek & $-0,008$ & 0,072 & $-0,006$ &,- 107 & 0,915 \\
\hline D2_Kamatok és költségek & $-0,337$ & 0,070 & $-0,243$ & $-4,800$ & 0,000 \\
\hline D1_Bankfiókok és ATM-ek elérhetősége & 0,165 & 0,071 & 0,121 & 2,330 & 0,021 \\
\hline D2_Bankfiókok és ATM-ek elérhetősége & $-0,212$ & 0,071 & $-0,152$ & $-2,995$ & 0,003 \\
\hline D1_Telefonos és internetes szolgáltatásminőség & 0,231 & 0,073 & $\mathbf{0 , 1 6 7}$ & 3,186 & 0,002 \\
\hline D2_Telefonos és internetes szolgáltatásminőség & $-0,036$ & 0,071 & $-0,026$ & $-0,507$ & 0,613 \\
\hline
\end{tabular}

Megjegyzés. $R^{2}=0,527$; korrigált $R^{2}=0,509 ; F=30,159(p<0,000)$. D1 az elégedettségre, D2 az elégedetlenségre utal. A szignifikáns értékeket vastagítva tüntettük fel.

A modellel, bár illeszkedése a dummy változók létrehozásából fakadó információvesztés miatt kissé rosszabb, mint az elsőé, jól ábrázolható az egyes teljesítménydimenziók hozzájárulása az elégedettséghez/elégedetlenséghez. (Lásd a 2. ábrát.)

2. ábra. A bankiszolgáltatás-dimenziók hozzájárulása az elégedettséghez, illetve elégedetlenséghez

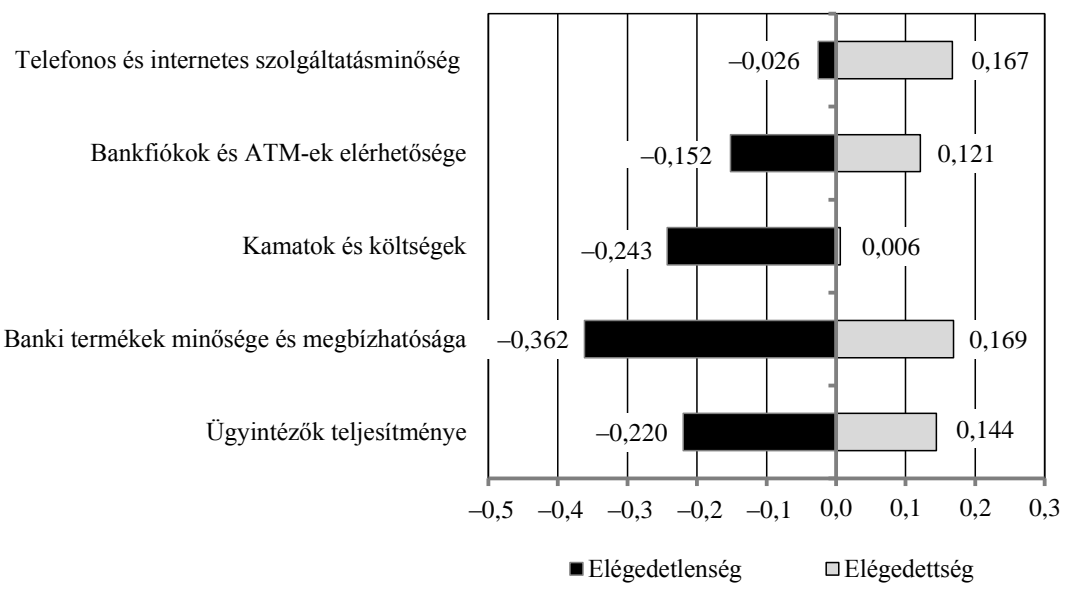

Statisztikai Szemle, 95. évfolỵam 1. szám 
A 2. ábra bizonyítja az elégedettséget pozitívan befolyásoló, illetve az elégedetlenségre okot adó teljesítménydimenziók közötti különbség létezését, azaz az elégedettség értelmezésében valóban szükséges a többdimenziós szemlélet. Mind az ügyintézők munkája, mind a bankfiókok és ATM-ek elérhetősége teljesítménytényezőnek tekinthető, azaz minél magasabb ezek színvonala, annál elégedettebbek lesznek a fogyasztók, míg hiányuk elégedetlenséghez vezet, azaz ezek közel azonos mértékben segítik elő vagy gátolják az elégedettséget. Nem mondható el viszont ugyanez a kamatokról és a költségekröl. A fogyasztók nehezményezik, ha magas költségeket ró rájuk a bank, tehát a kedvező feltételek hiánya nagyfokú elégedetlenséghez vezet, míg - érdekes módon meglétük nem okoz elégedettséget. Ezek tehát alaptényezőknek tekinthetők. Hasonló a helyzet a banki termékek minőségének és megbízhatóságának megítélésével is; bár a jó minőség/nagyfokú megbízhatóság hozzájárul az elégedettség kialakulásához, de sokkal kisebb mértékben, mint a kevésbé jó minőség/a megbízhatóság hiánya az ügyfelek elégedetlenségéhez. Az egyetlen tényező, amely lelkesítő tényezőnek tekinthetö, a telefonos és internetes szolgáltatások színvonala. Míg ennek gyengébb volta nem teszi elégedetlenné az ügyfeleket, magasabb szintje nagyban hozzájárul elégedettségükhöz.

\section{5. Összegzés}

A tanulmány első felében összefoglaltuk a különböző elégedettségmérési megközelítéseket, bemutatva, hogy az elégedettségmérés hagyományos, egydimenziós lineáris modellje mellett többféle módszer is létezik, amelyek többsége regresszióalapú becslés, és az egyes teljesítménydimenziók összelégedettségre vonatkozó hatását modellezi. A cikkben a háromdimenziós szemléletủ mérésre ismertettünk egy gyakorlati példát a GfK Hungária Piackutató Intézet adatbázisát felhasználva. Eredményeink alátámasztják az elégedettség aszimmetrikus hatását mérö háromdimenziós elégedettségmodellt.

Amennyiben elfogadjuk azt a megközelítést, hogy a vevői elégedettség az egyes teljesítmény-tényezők valamilyen összesített mutatója (ebben az értelemben tehát egy formatív mérőeszköz), akkor fontos e mutató előállításának lehetőségeit is vizsgálni. A háromdimenziós szemléletben az egyes teljesítménytényezők fontossága a tényező értékétől függően változhat, $s$ ennek megfelelően három eltérő mintázatot mutat. Az alaptényezők abban az esetben válnak fontossá, ha értékük alacsony, azaz hiányuk elégedetlenséghez vezet, túlteljesítésük azonban nem növeli az elégedettséget. A lelkesítő tényezők ezzel szemben az elégedettséghez járulnak hozzá, de hiányuk nem fokozza az elégedetlenséget. A teljesítménytényezők hatása pedig lineáris, azaz hiányuk elégedetlenséghez, többletteljesítésük elégedettséghez vezet. 
Kutatási példánkban egy bank ügyfeleinek elégedettségét elemeztük e szemléletben, és dummy változókon alapuló regressziós becslést mutattunk be. Eredményeink szerint a kamatok és költségek alaptényezönek tekinthetők: ha ezek nagyon magasak, akkor - érthető módon - a kiválasztott bank ügyfelei elégedetlenek. Érdekes módon azonban fordítva nem érzékelhető ez a hatás, hiszen a kedvezőbb kondíciók nem fokozzák az elégedettséget. Ennek az lehet az oka, hogy az ügyfelek negatívan tekintenek a költségfizetésre, és mivel banki környezetben hitelfelvétel esetén kamat mindig fizetendő, így nehezen tud elégedettséget növelő tényezővé válni. Az eredmények rámutattak arra, hogy az alaptényezők (így a banki kondíciók) javítása egy bizonyos ponton túl felesleges, hiszen nem növeli az ügyfelek elégedettségét. További erőforrásokat tehát erre nem érdemes allokálni. Ezzel szemben fontos lehet - föleg, ha a bank szeretne kiemelkedni versenytársai közül - beruházni lelkesítő tényezőkbe. (Példánkban a telefonos és az internetes banki szolgáltatások tartoznak ezekhez.) Ha a bankok ilyen jellegủ szolgáltatásai nem szofisztikáltak, ügyfeleik nem elégedetlenek, a jól müködő, magas színvonalon kínált szolgáltatások viszont nagyban növelhetik elégedettségüket, és megtartó erővel bírhatnak. A kutatási példánkban három teljesítménytényező rajzolódott ki, a banki ügyintézők szolgáltatásteljesítése, a fiók- és ATM-hálózat nagysága, valamint a banki termékek minősége és megbízhatósága. Míg az első kettő egyértelmüen lineáris hatást mutatott (tehát minél rosszabbul teljesítenek az ügyintézők /kevésbé kiterjedt a bank fiók- és ATM-hálózata, annál elégedetlenebbek az ügyfelek, és fordítva), addig a banki termékek minősége esetében jelentősebb volt a negatív hatás, tehát a gyenge minőség/rossz megbízhatóság nagyobb mértékben fokozza az emberek elégedetlenségét, mint a jó minőség/nagyfokú megbízhatóság az elégedettséget. E tényezők tekintetében tehát a banknak azt a célt kell kitüznie maga elé, hogy elérje/kissé meghaladja versenytársai színvonalát.

Fontos azt is megemlíteni, hogy kellő óvatossággal kell kezelni az elemzések eredményét, hiszen a módszerből fakadóan számtalan kutatói döntést kell hozni, amely befolyásolja azt. Ilyen többek között az alkalmazott skálák típusa vagy a dummy változók létrehozásának módszere. Ezekre ezért érdemes érzékenységi vizsgálatokat végezni.

Az elemzés során szem előtt kell tartani az eredmények változatosságát is. Célszerü például külön-külön vizsgálatot végezni az alapvetően elégedett és az alapvetően elégedetlen ügyfelekre vonatkozóan, hiszen lehetséges, hogy egészen más szempontok fontosak a két csoport számára. Ugyancsak eltérő eredményeket kaphatunk demográfiai vagy más szegmentációs ismérvek alkalmazásakor is. FüllerMatzler [2008] tanulmányában például az életstílus-változók alapján létrehozott szegmensek mutattak különböző elégedettségi mintázatokat.

Hasonlóképpen ajánlható a vizsgálat rendszeres elvégzése és a változások követése. Ekkor, még ha nem is egy azonos, longitudinális, de egy megfelelő valószínúségi minta rendszeres keresztmetszeti elemzésével növelhetjük az eredmények megbízhatóságát. 


\section{Irodalom}

ANDERSON, E. W. - MitTAL, V. [2000]: Strengthening the satisfaction-profit chain. Journal of Service Research. Vol. 3. No. 2. pp. 107-120.

Anderson, E. W. - Sullivan, M. W. [1993]: The antecedents and consequences of customer satisfaction for firms. Marketing Science. Vol. 12. No. 2. pp. 125-143. http://dx.doi.org/10.1287/mksc.12.2.125

ARbore, A. - BusACCA, B. [2009]: Customer satisfaction and dissatisfaction in retail banking: Exploring the asymmetric impact of attribute performances. Journal of Retailing and Consumer Services. Vol. 16. No. 4. pp. 271-280. http://dx.doi.org/10.1016/j.jretconser.2009.02.002

BARTIKOWSKI, B. - LlosA, S. [2004]: Customer satisfaction measurement: Comparing four methods of attribute categorisations. The Service Industries Journal. Vol. 24. No. 4. pp. 67-82. http://dx.doi.org/10.1080/0264206042000275190

BÁTOR A. [2007]: A vevőelégedettség és a lojalitás kapcsolata a kereskedelmi bankok szférájában (1. rész). Marketing \& Menedzsment. 51. évf. 2. sz. 4-15. old.

BRANDT, D. R. [1988]: How service marketers can identify value-enhancing service elements. The Journal of Services Marketing. Vol. 2. No. 3. pp. 35-41. http://dx.doi.org/10.1108/eb024732

CAdotte, E. R. - Turgeon, N. [1988]: Dissatisfiers and satisfiers: Suggestions from consumer complaints and compliments. Journal of Consumer Satisfaction Dissatisfaction and Complaining Behavior. Vol. 1. pp. 74-79. https://faculty.unlv.edu/gnaylor/JCSDCB/articles/1988\%20$\% 20 \% 20$ Volume\%201/Cadotte\%20et\%20al\%201988.pdf

Chang, K. C. - Chen, M. C. - Hsu, C. L. [2012]: Identifying critical brand contact elements of a tourist destination: Applications of Kano's model and the importance satisfaction model. International Journal of Tourism Research. Vol. 14. No. 3. pp. 205-221. http://dx.doi.org/10.1002/jtr.839

CHEN, L. H. - Ko, W. C. [2008]: A fuzzy nonlinear model for quality function deployment considering Kano's concept. Mathematical and Computer Modelling. Vol. 48. Nos. 3-4. pp. 581-593. http://dx.doi.org/10.1016/j.mcm.2007.06.029

Chen, L. H. - Weng, M. C. [2003]: A fuzzy model for exploiting quality function deployment. Mathematical and Computer Modeling. Vol. 38. Nos. 5-6. pp. 559-570. http://dx.doi.org/10.1016/S0895-7177(03)90027-6

ChurChill JR., G. A. - SuRPREnANT, C. [1982]: An investigation into the determinants of customer satisfaction. Journal of Marketing Research. Vol. 19. No. 4. pp. 491-504. http://dx.doi.org/10.2307/3151722

Conklin, M. - PowAGA, K. - LiPOVETSKY, S. [2004]: Customer satisfaction analysis: Identification of key drivers. European Journal of Operational Research. Vol. 154. No. 3. pp. 819-827. http://dx.doi.org/10.1016/S0377-2217(02)00877-9

CRONIN, J. J. - TAYLOR, S. A. [1994]: SERVPERF versus SERVQUAL: Reconciling performancebased and perceptions-minus-expectations measurement of service quality. Journal of Marketing. Vol. 58. No. 1. pp. 125-131. http://dx.doi.org/10.2307/1252256

FülleR, J. - MATZleR, K. [2008]: Customer delight and market segmentation: An application of the three-factor theory of customer satisfaction on life style groups. Tourism Management. Vol. 29. No.1. pp. 116-126. http://dx.doi.org/10.1016/j.tourman.2007.03.021 
GREMLER, D. D. [2004]: The critical incident technique in service research. Journal of Service Research. Vol. 7. No. 1. pp. 65-89. http://dx.doi.org/10.1177/1094670504266138

HeLson, H. [1964]: Current trends and issues in adaptation-level theory. American Psychologist. Vol. 19. No. 1. pp. 26-38. http://dx.doi.org/10.1037/h0040013

HETESI E. [2003]: A lojalitás definiálási és mérési problémái, a lojalitás hatása a jövedelmezőségre. Vezetéstudomány. XXXIV. évf. 1. sz. 20-27. old.

Hofmeister Tóth Á. - Simon J. - Sajtos L. [2003]: A fogyasztói elégedettség. Alinea. Budapest.

JoHnSTON, R. [1995]: The determinants of service quality: Satisfiers and dissatisfiers. International Journal of Service Industry Management. Vol. 6. No. 5. pp. 53-71. http://dx.doi.org $/ 10.1108 / 09564239510101536$

JoHnston, R. [1997]: Identifying the critical determinants of service quality in retail banking: Importance and effect. International Journal of Bank Marketing. Vol. 15. No. 4. pp. 111-116. http://dx.doi.org/10.1108/02652329710189366

KAHNEMAN, D. - TVERSKY, A. [1979]: Prospect theory: An analysis of decision under risk. Econometrica. Vol. 47. No. 2. pp. 263-291. http://dx.doi.org/10.2307/1914185

KANO, N. [1984]: Attractive quality and must-be quality. Journal of the Japanese Society for Quality Control. Vol. 14. No. 2. pp. 39-48.

KAZÁR K. [2014]: A PLS-útelemzés és alkalmazása egy márkaközösség pszichológiai érzetének vizsgálatára. Statisztikai Szemle. 92. évf. 1. sz. 33-52. old.

KEMÉNY I. [2015]: A versenytársak csak egy kattintásra vannak. Az újravásárlási és továbbajánlási szándék alakulása különbözö e-kereskedelmi kategóriákban. PhD-értekezés. Budapesti Corvinus Egyetem. Budapest.

KENESEI Zs. - SZÁNTÓ Sz. [1998]: A szolgáltatásminősítés mérése - elmélet és gyakorlat. Vezetéstudomány. XXIX. évf. 12. sz. 8-18. old.

KeNESEI Zs. - Kolos K. [2008]: A hatékony panaszkezelés lehetőségei: kompenzáció és bocsánatkérés. Vezetéstudomány. XXXIX. évf. 5. sz. 27-39. old.

KovÁCS A. [2015]: Strukturális egyenletek modelljének alkalmazása a Közös Agrárpolitika 2013as reformjának elemzésére. Statisztikai Szemle. 93. évf. 8-9. sz. 801-822. old.

KRENYÁCZ É. [2015]: A hazai egészségügyi intézmények kontrolling-rendszere. Statisztikai Szemle. 93. évf. 8-9. sz. 823-857. old.

Lipovetsky, S. - ConkLin, M. [2001]: Analysis of regression in game theory approach. Applied Stochastic Models Business and Industry. Vol. 17. No. 4. pp. 319-330. http://dx.doi.org/10.1002/asmb.446

MANO, H. - Oliver, R. L. [1993]: Assessing the dimensionality and structure of the consumption experience: Evaluation, feeling and satisfaction. Journal of Consumer Research. Vol. 20. Issue 3. pp. 451-466. http://dx.doi.org/10.1086/209361

MARTILlA, J. A. - JAMES, J. C. [1977]: Importance-performance analysis. Journal of Marketing. Vol. 41. No. 1. pp. 77-79. http://dx.doi.org/10.1108/03090569310026402

Matzler, K. - BAilom, F. - HinTerhuber, H. H. - RenZl, B. - Pichler, J. [2004]: The asymmetric relationship between attribute-level performance and overall customer satisfaction: A reconsideration of the importance-performance analysis. Industrial Marketing Management. Vol. 33. pp. 271-277. http://dx.doi.org/10.1016/S0019-8501(03)00055-5 
MAtZler, K. - Hinterhuber, H. H. [1998]: How to make product development projects more successful by integrating Kano's model of customer satisfaction into quality function deployment. Technovation. Vol. 18. No. 1. pp. 25-38. http://dx.doi.org/10.1016/S01664972(97)00072-2

Matzler, K. - RenZl, B. - FAUllant, R. [2007]: Dimensions of price satisfaction: A replication and extension. International Journal of Bank Marketing. Vol. 25. No. 6. pp. 394-405. http://dx.doi.org/10.1108/02652320710820345

MATZLER, K. - SAUERWEIN, E. [2002]: The factor structure of customer satisfaction: An empirical test of the importance grid and the penalty-reward-contrast analysis. International Journal of Service Industry Management. Vol. 13. No. 4. pp. 314-332. http://dx.doi.org /10.1108/09564230210445078

MAtZler, K. - SAUERWein, E. - Heischmidt, K. [2003]: Importance-performance analysis revisited: The role of the factor structure of customer satisfaction. The Service Industries Journal. Vol. 23. No. 2. pp. 112-129. http://dx.doi.org/10.1080/02642060412331300912

Matzler, K. - Würtele, A. - RenZl, B. [2006]: Dimensions of price satisfaction: A study in the retail banking industry. International Journal of Bank Marketing. Vol. 24. No. 4. pp. 216-231. http://dx.doi.org/10.1108/02652320610671324

Meuter, M. L. - Ostrom, A. L. - Roundtree, R. I. - Bitner, M. J. [2000]: Self-service technologies: Understanding customer satisfaction with technology-based service encounter. Journal of Marketing. Vol. 64. No. 3. pp. 50-64. http://dx.doi.org/10.1509/jmkg.64.3.50.18024

Mittal, V. - Ross, W. T. R. - BALdasare, P. M. [1998]: The asymmetric impact of negative and positive attribute-level performance on overall satisfaction and repurchase intentions. Journal of Marketing. Vol. 62. No. 1. pp. 33-47. https://doi.org/10.2307/1251801

NisAR T. - Yeung, M. [2015]: Purchase Conversions and Attribution Modeling in Online Advertising: An Empirical Investigation. Proceedings of the EMAC 2015 Conference. http://eprints.soton.ac.uk/380534/1/GHLEFMG_FGMJHM_VJ1QM9QF.pdf

OLIVER, R. L. [1977]: Effect of expectations and disconfirmation on postexposure product evaluations: An alternative interpretation. Journal of Applied Psychology. Vol. 62. No. 4. pp. 480486. http://dx.doi.org/10.1037/0021-9010.62.4.480

Oliver, R. L. [1993]: Cognitive, affective, and attribute bases of the satisfaction response. Journal of Consumer Research. Vol. 20. No. 3. pp. 418-430. http://dx.doi.org/10.1086/209358

PARASURAMAN, A. - ZeithamL, V. A. - BerRy, L. L. [1988]: SERVQUAL: A multiple-item scale for measuring consumer perceptions of service quality. Journal of Retailing. Vol. 64. No. 1. pp. 12-40.

Peter, J. P. - Churchill JR., G. A. - Brown, T. J. [1993]: Caution in the use of difference scores in consumer research. Journal of Consumer Research. Vol. 19. Issue 4. pp. 655-662. http://dx.doi.org/10.1086/209329

PINTÉR M. [2007]: Regressziós játékok. Szigma. XXXVIII. évf. 3-4. sz. 131-148. old.

SzŐCS A. - BERÁCS J. [2015]: A fogyasztói márkaérték, mint másodrendủ látens változó okozati becslése. Szigma. XLVI. évf. 1-2. sz. 99-125. old.

Szymanski, D. M. - HenARD, D. H. [2001]: Customer satisfaction: A meta-analysis of the empirical evidence. Journal of the Academy of Marketing Science. Vol. 29. No. 1. pp. 16-35. http://dx.doi.org/10.1177/009207030102900102 
TING, S.-C. - CHEN, C.-N. [2002]: The asymmetrical and non-linear effects of store quality attributes on customer satisfaction. Total Quality Management. Vol. 13. No. 4. pp. 547-569. http://dx.doi.org/10.1080/09544120220149331

VAVRA, T. G. [1997]: Improving Your Measurement of Customer Satisfaction. A Guide to Creating, Conducting, Analyzing, and Reporting Customer Satisfaction Measurement Programs. American Society for Quality. Milwaukee.

WeStBROOK, R. A. [1987]: Product/consumption-based affective responses and postpurchase processes. Journal of Marketing Research. Vol. 24. Issue 3. pp. 258-270. http://dx.doi.org $/ 10.2307 / 3151636$

Zeithaml, V. A. - Berry, L. L. - PARASuraman, A. [1996]: The behavioral consequences of service quality. Journal of Marketing. Vol. 60. No. 2. pp. 31-46. http://dx.doi.org /10.1080/07359683.2015.1000706

\section{Summary}

Customer satisfaction - that has a central role in company decisions - can lead to higher profitability and long-term competitive advantage. To reach customer satisfaction, companies have to measure and analyse its driving factors. Still, many of them only measure customer satisfaction but fail to examine results.

First, the paper presents measurement methods and the multi-dimensional satisfaction concept. Then, it introduces the empirical results of a regression-analysis-based three-dimensional approach using dummy variables. The results are particularly relevant for those managers who make resource allocation decisions based on customer satisfaction studies. 